\title{
Approaches to the discovery of non-invasive urinary biomarkers of prostate cancer
}

\author{
Andrej Jedinak ${ }^{1,2}$, Kevin R. Loughlin ${ }^{2,3}$ and Marsha A. Moses ${ }^{1,2}$ \\ ${ }^{1}$ Vascular Biology Program and Department of Surgery, Boston Children's Hospital, Boston, MA, USA \\ ${ }^{2}$ Department of Surgery, Harvard Medical School, Boston, MA, USA \\ ${ }^{3}$ Department of Urology, Brigham and Women's Hospital, Boston, MA, USA \\ Correspondence to: Marsha A. Moses, email: marsha.moses@childrens.harvard.edu \\ Keywords: prostate cancer; biomarkers; non-invasive; proteomics \\ Received: May 16, $2018 \quad$ Accepted: July 23, $2018 \quad$ Published: August 21, 2018 \\ Copyright: Jedinak et al. This is an open-access article distributed under the terms of the Creative Commons Attribution License \\ 3.0 (CC BY 3.0), which permits unrestricted use, distribution, and reproduction in any medium, provided the original author and \\ source are credited.
}

\section{ABSTRACT}

Prostate cancer ( $\mathrm{PCa}$ ) continues to be one of the most common cancers in men worldwide. Prostate specific antigen (PSA) measured in blood has been used for decades as an aid for physicians to detect the presence of prostate cancer. However, the PSA test has limited sensitivity and specificity, leading to unnecessary biopsies, overdiagnosis and overtreatment of patients. For these reasons, there is an urgent need for more accurate PCa biomarkers that can detect PCa with high sensitivity and specificity. Urine is a unique source of potential protein biomarkers that can be measured in a non-invasive way. This review comprehensively summarizes state of the art approaches used in the discovery and validation of urinary biomarkers for PCa. Numerous strategies are currently being used in the discovery of urinary biomarkers for prostate cancer including gel-based separation techniques, mass spectrometry, activity-based proteomic assays and software approaches. Antibodybased approaches remain preferred method for validation of candidate biomarkers with rapidly advancing multiplex immunoassays and MS-based targeted approaches. In the last decade, there has been a dramatic acceleration in the development of new techniques and approaches in the discovery of protein biomarkers for prostate cancer including computational, statistical and data mining methods. Many urinarybased protein biomarkers have been identified and have shown significant promise in initial studies. Examples of these potential biomarkers and the methods utilized in their discovery are also discussed in this review.

\section{INTRODUCTION}

Prostate cancer $(\mathrm{PCa})$ is the most prevalent cancer in males and it is estimated that approximately 116,000 men living in USA were diagnosed with prostate cancer in 2017 [1]. The majority of the men (62\%) diagnosed with $\mathrm{PCa}$ are 70 years or older with a median age of diagnosis at 66 years, thus reflecting the disease typically present in older men [2]. The majority of prostate tumors arise from the epithelial cells of the prostate peripheral zone with approximately $20-30 \%$ arising in the transition zone
[3]. The most common non-malignant prostate disease significantly affecting aging men is benign prostatic hyperplasia (BPH), which is generally a disease of the transition zone [4]. These two prostatic diseases share similar symptoms and currently no reliable test exists with high specificity and selectivity that can differentiate between these two prostate diseases [5]. Another critical challenge is to differentiate between indolent or localized $\mathrm{PCa}$ from aggressive cancer [6] and reliably identify patients who would benefit from an active surveillance program [7]. Currently, a prostate cancer diagnosis is 
based on age, family history, race, prostatic digital rectal examination findings (DRE) and elevated levels of prostate specific antigen (PSA) in blood. However, none of these can reliably differentiate whether the patient has benign disease or prostate cancer. Therefore, a diagnostic dilemna exists and clinicians often recommend a prostate biopsy. This is a highly invasive approach, which is associated with high risk of bleeding, infection, urinary difficulty and hospitalization for signs of prostatitis or urosepsis, hematuria and hematospermia [8]. In addition, prostate biopsies can lead to sampling error, either missing the significant lesion or cancer completely [7], leading to false-negative results [9]. Thus, there is a pressing clinical need for an accurate PCa diagnosis to decrease unnecessary prostate biopsies [6].

In 1986, to guide clinical decision making, the US Food and Drug Administration approved the PSA test as a diagnostic, screening, and monitoring tool for the early detection of prostate cancer [10]. Prostate specific antigen (PSA) is a kallikrein serine protease (hK3) encoded by the KLK3 gene [11]. It was first purified in 1979 [12] and detected in serum in 1980 [13]. PSA is a 30-33 kDa protein [4], biologically responsible for semen liquefaction [14] that is secreted into the seminal fluid by luminal epithelial cells of the ducts and acini in the prostate. Normal basement membranes of prostatic ducts and acini as well as prostatic stroma limit the PSA release into the blood circulation [4]. Human kallikrein-3, also known as PSA, became the most widely used serum biomarker for the detection of PCa [6]. However, an elevated serum prostate-specific antigen (PSA) can be detected with either benign or malignant growth of the prostate [5]. PSA also can be elevated in prostatitis or physical trauma of the prostate thereby indicating pathologies of the prostate gland that are not necessarily cancer [14]. In addition, manipulations of the prostate (digital rectal examination [DRE], biopsy, catheterization, ejaculation) can also lead to elevated levels of PSA in blood [15]. Interestingly, PSA was also found to be expressed in the periurethral glands [16], normal breast tissue and various tumors [17]. Unfortunately then, PSA's main drawback is lack of specificity and sensitivity leading to unnecessary biopsies, over-diagnosis and overtreatment of insignificant PCa tumors [11]. A negative prostate biopsy is found in $65 \%$ to $70 \%$ of men with a PSA between 4.0 and $10.0 \mathrm{ng} / \mathrm{ml}^{-1}$ and PSA has only a $25-40 \%$ positive predictive value to detect $\mathrm{PCa}[18$, 19]. Up to $15 \%$ men with PCa have a PSA levels below 4.0 $\mathrm{ng} / \mathrm{ml}^{-1}$ thereby leaving certain cancers undetected [20]. To address these issues, a variety of permutations of PSA (ageadjusted PSA ranges, PSA velocity, PSA density, and free PSA fraction) have been used to improve the diagnostic sensitivity and specificity of PSA screening [5]. Nevertheless, all these PSA variations have been unsatisfactory in their capacity to differentiate between $\mathrm{BPH}$ and $\mathrm{PCa}$ in a clinical setting [21]. The potential of misdiagnosis, harms and small benefits resulting from PSA screening [22] lead the United States Preventive Services Task Force (USPSTF) in May of 2012 to not recommend PSA screening for PCa [5]. To summarize, there is a critical need for better quality $\mathrm{PCa}$ biomarkers that are noninvasive, have improved accuracy, and improved risk stratification properties [6]. In addition, a unified approach fulfilling the Reporting Recommendations for Tumor Marker Prognostic Studies (REMARK) [23] criteria that includes prospective studies and identification of optimal combinations of biomarkers is needed and critical to accurately identify and validate reliable urinary protein biomarkers for PCa that would allow the clinician to make more accurate clinical decisions.

\section{URINE AS A SOURCE OF PROSTATE CANCER BIOMARKERS}

Urine is a biofluid enriched with proteins that reflect the physiological or pathological state of major urological tissues, including the prostate [24]. Urine also contains proteins that are secreted or have come in contact with the prostate making it an attractive liquid biopsy source of prostate biomarkers. The human urinary proteome was reported to contain approximately 2,000 proteins, including membrane, extracellular and lysosomal proteins $[25,26]$. However, a recent study reported a total of 6,085 proteins identified in healthy urine [27] representing approximately one third of the whole human proteome which is currently estimated to consist of approximately 20,000 proteins [28]. Approximately $150 \mathrm{mg}$ of proteins $[25,29]$ and $1-4 \mathrm{~g}$ of peptides are excreted in human urine by a healthy person each day [29]. It has been reported that the total urine output is approximately $1.5 \mathrm{liter} /$ day/person [26], thus providing a more than sufficient amount for proteomic analysis [30]. In contrast, only a few microliters are often available to collect from small animals such as mice [31] therefore urine volume might be a limiting factor for proteomic analysis such that samples might need to be pooled. Collection of urine is very simple, can be noninvasively [32] collected over time in large amounts, and readily archived for processing [33] without having a high proteome background such as plasma. Urine can be stored for several months at $-20^{\circ} \mathrm{C}$ or for several years at $-80^{\circ} \mathrm{C}$ without, in many cases significantly changing the human urinary proteome. It is known that the human urinary proteome changes with disease status, thus making urine one of the most attractive biofluids for discovery of prognostic, diagnostic and monitoring biomarkers. In summary, urine is one of the most interesting and useful biofluids in PCa biomarker discovery and can be obtained non-invasively in large quantities.

\section{PROTEOMICS IN PROSTATE CANCER BIOMARKER DISCOVERY}

Proteomics is the large-scale study of proteins [33] which offers complementary information to genomic and 
transcriptomic studies essential for understanding complex biochemical processes [34]. It can also be defined as a postgenomic discipline that encompasses efforts to identify and quantify all the proteins of a proteome [35]. The proteome is the complete set of proteins found in living cells, tissues or organisms, representing the end result of gene transcription, translation and protein synthesis up through post-translational protein modification (PTM) [36]. However, analysis of the human proteome is very challenging due to its unique characteristics which include a high dynamic range of protein expression [37], alternative splicing events, interconnectivity of proteins into complexes and signaling networks [38] and significant complexity due to an excess of PTMs and sequence variations [37]. Protein activity, stability, localization, and function are also often modulated by PTMs [37, 39]. A number of human diseases, including cancer, have been previously linked to PTMs, such as protein acetylation, glycosylation, hydroxylation, and phosphorylation $[37,40]$. Due to the complexity of the proteome, the progress of proteomics has been driven by the development of new technologies for peptide/protein separation, mass spectrometry analysis, isotope labeling for quantification, and bioinformatics data analysis. Mass spectrometry (MS) has emerged as a powerful technique to identify, characterize, and quantify proteins and their PTMs with high throughput and on a large scale [34]. MS is frequently used as a discovery tool with high sensitivity and specificity that plays a crucial role in biomarker discovery. In the past decade, MS methods have been employed in liquid biopsy approaches and the discovery of numerous protein biomarkers of various cancers thereby representing a cornerstone of protein-based cancer biomarker discovery [33].

\section{Proteomic strategies involving mass spectrometry}

In mass spectrometry-based proteomics there are two distinct approaches in proteomics analysis: the less used, less mature "top-down" proteomics, and the almost universally used "bottom-up" proteomics [41]. Protein identification by top-down proteomics involves analysis of intact protein [39] without enzymatic treatment, followed by protein ionization and LC-MS analysis [28]. One of the advantages of the top-down approach is that it provides reduced sample complexity in comparison to the proteins digested and analyzed by using the bottomup approach [37]. Another advantage is that it allows the characterization of proteoforms, protein isoforms and PTMs [42]. However, the top-down method has significant limitations compared to bottom-up proteomics due to difficulties with protein fractionation, protein ionization, and fragmentation in the gas phase [35]. In contrast, chemical or enzymatic treatment of proteins into smaller peptides, followed by MS analysis is characteristic of a bottom-up strategy [33]. Peptides are usually identified by specific bioinformatics tools to match tandem mass spectra (MS/MS) with the theoretical fragmentation patterns generated using a genomic database [34]. Also included in this category is the "shotgun" proteomics approach wherein the mixture of proteins in a sample is digested and then analyzed by mass spectrometry without first separating individual whole proteins [24]. An automated variant of shotgun proteomics named multidimensional protein identification technology (MudPIT) has been developed, which incorporates multidimensional highpressure liquid chromatography (LC/LC), tandem mass spectrometry (MS/MS) and database-searching algorithms [43]. An important part of biomarker discovery is MS-based protein quantification where biomarkers are typically identified through changes in protein or peptide concentrations between sample groups [44]. Common methods rely on label-free quantification or label-based quantification of proteins or peptides [45]. Stable isotope label-based quantification can be categorized from a MS point of view as "isotopic" or "isobaric." The main difference between these two methods is that isotopic approaches such as SILAC (stable isotope labeling by amino acids in cell culture), ICAT (isotope-coded affinity tag) and ICPL (isotope-coded protein label) methods measure ion intensities of light and heavy isotopes of a peptide for quantification at the MS level. In contrast, isobaric methods including TMT (tandem mass tags) and iTRAQ (isobaric tags for relative and absolute quantitation) quantify peptides at the MS/MS level based on comparison of the reporting peaks with different isotopic labeling [46]. Our group has recently conducted a study utilizing the iTRAQ approach to discover new urinary biomarkers that could distinguish between benign prostate hyperplasia (BPH) and localized prostate cancer. We utilized an 8-plex iTRAQ format in which four urine samples from patients diagnosed with BPH and 4 urine samples from patients diagnosed with $\mathrm{PCa}$ were analyzed. One advantage of using the 8-plex iTRAQ format is that it permits the simultaneous identification and quantification of multiple samples under the same experimental conditions. Moreover, this system also allows one sample to be used as an internal reference, thus allowing for crossset comparison. We identified, with high confidence, 25 proteins whose levels were significantly different between these two groups. Surprisingly, these proteins range widely in function from cell assembly and organization, cell signaling, cell morphology, carbohydrate metabolism, cellular growth and proliferation, lipid metabolism, androgen and estrogen metabolism, DNA replication, recombination and repair, among others. Three proteins, $\beta 2 \mathrm{M}$ ( $\beta 2$-microglobulin), PGA3 (pepsinogen 3), and MUC3 (mucin 3), were found to be significantly different between urine samples from BPH patients and samples from prostate cancer patients through univariate analysis. These proteins, either alone or when multiplexed, showed 
significant sensitivity and specificity in discriminating between patients with $\mathrm{BPH}$ and those with localized prostate cancer. In addition, these new biomarkers significantly increased predictive accuracy based on PSA categories from 0.734 to 0.812 when combined $(\mathrm{P}=0.004$, Delong test for comparing ROC curves) [5]. In another study, we used tandem MS/MS mass spectrometry in combination with chromatography and zymography to identify high molecular weight gelatinase (HMW) species in urine from patients with different cancers. Distinct MMP fingerprints were identified for organ-confined prostate cancer vs. bladder cancer. MMP-9 dimer and MMP-9 monomer were multivariable predictors for distinguishing between patients with prostate and bladder cancer $(P<0.001$ for each $)$ [47].

The label-free protein quantification approach is based either on the comparison of extracted peptide MS peak intensities from different biological samples (intensity-based quantitation) or on the total number of MS/MS acquired for the same peptide (spectral counting approach) to represent the relative abundance of this peptide in the mixture [34]. The sample processing is simple, relatively inexpensive (no labeling reagent involved) and offers greater dynamic range and proteome coverage compared to label-based methods [48]. In addition, this is a very high throughput technique frequently used in the discovery of urinary proteome biomarkers from human samples [49]. However, labelfree approaches also have some disadvantages, such as reproducibility between sample runs [44], redundancy in peak detection, lower accuracy, a semi-quantitative nature, and the lack of unsuitability for low abundance and small proteins [49]. Contrary to quantitative protein profiling, which is an unbiased proteomic approach, targeted quantitative proteomics is a candidate-based method that permits specific detection of selected analytes in a complex system [46]. Targeted quantitative proteomics is based on a hypothesis-driven selection of the proteins of research interest, while nontargeted peptides are not analyzed [50]. Targeted detection and quantification of candidate biomarkers is generally achieved by selected reaction monitoring (SRM), also referred to as multiple reaction monitoring (MRM) [44]. The SRM/MRM technique is considered the gold standard proteomic quantification method for predefined sets of proteins [50]. SRM is a nonscanning method that is performed on triple quadrupole-type instruments (QqQ) [51]. The first quadrupole (Q1) is used to isolate specified precursor ions, the second quadrupole (Q2) serves as the collision cell to activate and dissociate the precursor ion, and the third quadrupole (Q3) is used to isolate the specific product ion [52]. This SRM technique offers high-throughput performances, high selectivity and sensitivity, wide dynamic range of measurements and high reproducibility $[50,53]$. Nevertheless, the selectivity of this mass spectrometry is reduced by the resolving power of its mass analyzers such that interferences may require reanalyzing the samples. Despite the efforts undertaken to limit the shortcomings, the process still remains laborious and time consuming [54]. Recently, targeted mass spectrometry-based approaches have been widely used for quantitative proteomics studies and have been applied on to high resolution/accurate mass (HRAM) instruments, such as the quadrupole-time of flight (Q-TOF) and quadrupole-orbitrap (Q-OT) resulting in a substantial performance enhancement [55]. More precisely, analyses executed on quadrupole-orbitrap mass spectrometers operated in parallel reaction monitoring (PRM) mode leverage intrinsic high resolving power and trapping capabilities [53] thereby offering a clear advantage over the conventional SRM measurements executed on triple quadrupole instruments [55]. The potential of the PRM technique offers very high degrees of selectivity and analytical sensitivity, usually required to analyze peptides in complex samples, such as those used in biomedical research or clinical studies [53].

To accurately and quantitatively analyze data in MS-based approaches, computational methods and common search engines are used to help facilitate quick data analysis [33]. The most widely used computational methods are based on the use of protein sequence databases, search engines, de novo sequencing and spectral libraries [56]. Consequently, several well established applications for peptide identification are now being used worldwide including Sequest [57], X!Tandem [58], Mascot [59], MyriMatch [60] or Andromeda [61]. These tools first perform an in silico digestion of all proteins in a reference protein database to compute all candidate peptide sequences and then build a theoretical spectrum for each candidate peptide sequence [62]. The expected endpoint for most datasets obtained for research purposes is storage in public data repositories thus allowing access for other researchers [63]. Several well-known proteomics databases have been developed including, Global Proteome Machine Database (GPMDB) [64], PeptideAtlas [65], and the PRIDE database [66]. In addition, there are currently a few databases that are more specific to the human urine proteome such as MAPU [67], SysBodyFluid [68], HKUPP [69], Urinary Exosome Protein Database [70], Urinary Protein Biomarker Database [71], Mosaiques Diagnostics database [72] and UPdb [73].

\section{Proteomic approaches}

In general, there are two commonly used proteomic separation techniques, gel-based and gel-free methods (Figure 1).

\section{Techniques utilizing gels}

The two most common gel-utilizing methods to fragment and set apart proteins in a gel-based substance are 1-dimensional (1D) and 2-dimensional (2D) gel 
electrophoresis. After gel electrophoresis, proteins are cut out from the gel, processed with a protease such as endopeptidase trypsin, and the resulting peptide fragments are examined using MS [33, 74]. In one of our studies, 1D SDS-PAGE gel electrophoresis in combination with column chromatography, zymography, and tandem MS (MS/MS) facilitated the identification of MMP-2 $(P<$ $0.001)$ and MMP-9/NGAL $(P=0.003)$ by multivariable regression as independently predictive in differentiating prostate cancer patients and controls. In addition, MMP9 and MMP-9 dimer were identified as multivariable predictors for differentiating prostate from bladder cancer $(P<0.001)$ [47]. In a recent study, 2-D DIGE gel electrophoresis coupled with MS and bioinformatics analysis identified serotransferrin (TF), alpha-1microglobulin/bikunin precursor (AMPB) and haptoglobin ( $\alpha$-chain) (HP) as new urinary biomarkers, which could distinguish between BPH and prostate cancer. The area under the curve (AUC) for the individual proteins ranged from 0.723 for $\operatorname{HP}(p=0.008), 0.738$ for $\operatorname{AMBP}(p=0.005)$ and 0.754 for $\mathrm{TF}(\mathrm{p}=0.002)$. In another recent study, 2-D PAGE followed by matrix-assisted laser desorption ionization-time of flight-mass spectroscopy (MALDITOF-MS) identified calgranulin/MRP-14 as a potential biomarker in voided urine that distinguishes between $\mathrm{BPH}$ and $\mathrm{PCa}$ [75]. Due to such drawbacks as a limited protein dynamic range and issues with incomplete digestion, gelfree proteomics soon became a preferred approach $[7,36]$.

\section{Comparison of acquisition methods, cost-effectiveness and reproducibility}

Development of new technologies and tools in the last decade significantly accelerated progress in proteomics approaches and biomarker discovery. However, an open question remaining is the determination of which specific proteomic approach is the most appropriate to use in biomarker discovery and validation when using clinical samples [76]. Several studies have compared proteomic approaches for protein identification and quantification in human specimens. For example, 2D DIGE, ICAT and iTRAQ were compared in a protein profiling study [77] that showed that iTRAQ offered better quantitative reproducibility and higher sensitivity than 2D DIGE or ICAT [77]. In a separate study, iTRAQ 4-plex versus 8-plex were compared with respect to protein quantitation in human plasma samples. The data revealed that iTRAQ 8-plex provided more consistent ratios than the 4-plex without compromising protein identification and offered higher sample throughput than 4-plex [78]. Moreover, multiple studies compared label-free proteomics with label-based methods such as SILAC [79], 8-plex iTRAQ [76] or the 6-plex TMT approach [80] for protein identification and quantification. Taken together, these studies suggested that label-free proteomic approaches provide better protein coverage and outperform the label- based methods. Generally, shotgun MS approaches appear to be the preferred choice used for discovery studies, while directed and targeted MS methods are commonly used in verification and validation studies [79]. However, more "head to head" and "side by side" studies comparing the suitability of particular proteomic methods in biomarker discovery and development are needed.

Overtreatment and overdiagnosis of PCa patients significantly raises the cost of health care. Therefore, a novel economical, non-invasive approach, which would limit the number of biopsies, could also lead to the reduced cost. For example, analysis of urine from PCa patients performed by capillary electrophoresis mass spectrometry (CE/MS) outperformed the biopsy approach as well as the PSA test. Moreover, a majority of cost savings were related to the significant reduction in the number of necessary biopsies by 49\% [81]. Cost-effectiveness can also be achieved by more accurate tests. For instance, the use of the SelectMDx test after PSA ( $>3 \mathrm{ng} / \mathrm{ml})$ as a second diagnostic tool to inform the need for prostate biopsies led to savings of $€ 128$ and an increase of 0.025 quality-adjusted life years (QALY) per patient versus the standard of care strategy (PSA+DRE) [82]. Addition of the Prostate Health Index (PHI) testing for men with elevated serum PSA is another example where the number of negative biopsies can be significantly reduced, leading to better detection and improved cost-effectiveness [83].

There is a limited literature regarding reproducibility of the urinary proteomic profile [84] and therefore a significant need to address this issue. Discovery proteomic methods including chemical labeling and label-free approaches showed, in general, a high degree of protein and peptide detection reproducibility in urine $[85,86]$. Targeted proteomic approaches such as SRM/ MRM demonstrated high reproducibility of detected proteins in urine samples and results were comparable to those obtained by ELISA [87]. However, more studies comparing proteomic approaches are needed.

\section{Advantages and disadvantages of the use of the proteomics approaches}

While advances such as new instruments, techniques and software have led to the evolution of novel proteomic approaches for identification and validation of protein biomarkers, there also exist a variety of challenges and limitations associated with this approach. For example, gel-based techniques are frequently used in discovery but are not applicable in clinical settings due their time consuming nature, lack of high-throughput capabilities, requirement for high antibody quality and need for continuous optimization. MS-based methods are very sensitive, specific and generate significant amounts of information and, as such, are now gradually being incorporated into clinical settings. However, there are also some drawbacks 
associated with MS-based methods such as the need for expensive hardware, specific software, expensive equipment maintenance fees, high cost of certain chemicals, low-throughput and the requirement of highly skilled personal. Functional assays are highly specific and provide activity readouts, but their use can be limited due the availability and cost of commercial antibodies or reporter tags. ELISA-based methods are simple, fast, have high-throughput, can be performed by trained technician, and can be highly sensitive and specific. This technique is frequently used in validation of proteomic discoveries and in clinical settings as well.
However, detection of only a single antigen at a time is an important limitation which is being addressed by the development of a number of multiplex immunoassays.

\section{Strategies with functional proteomic technology}

Proteases play a key role in normal physiological functions in the body. However, dysfunction in the biological control mechanisms of proteases may contribute to various diseases, including cancer and cancer metastasis [88]. Therefore, detection and quantification of proteases in body fluids, including urine, may be useful

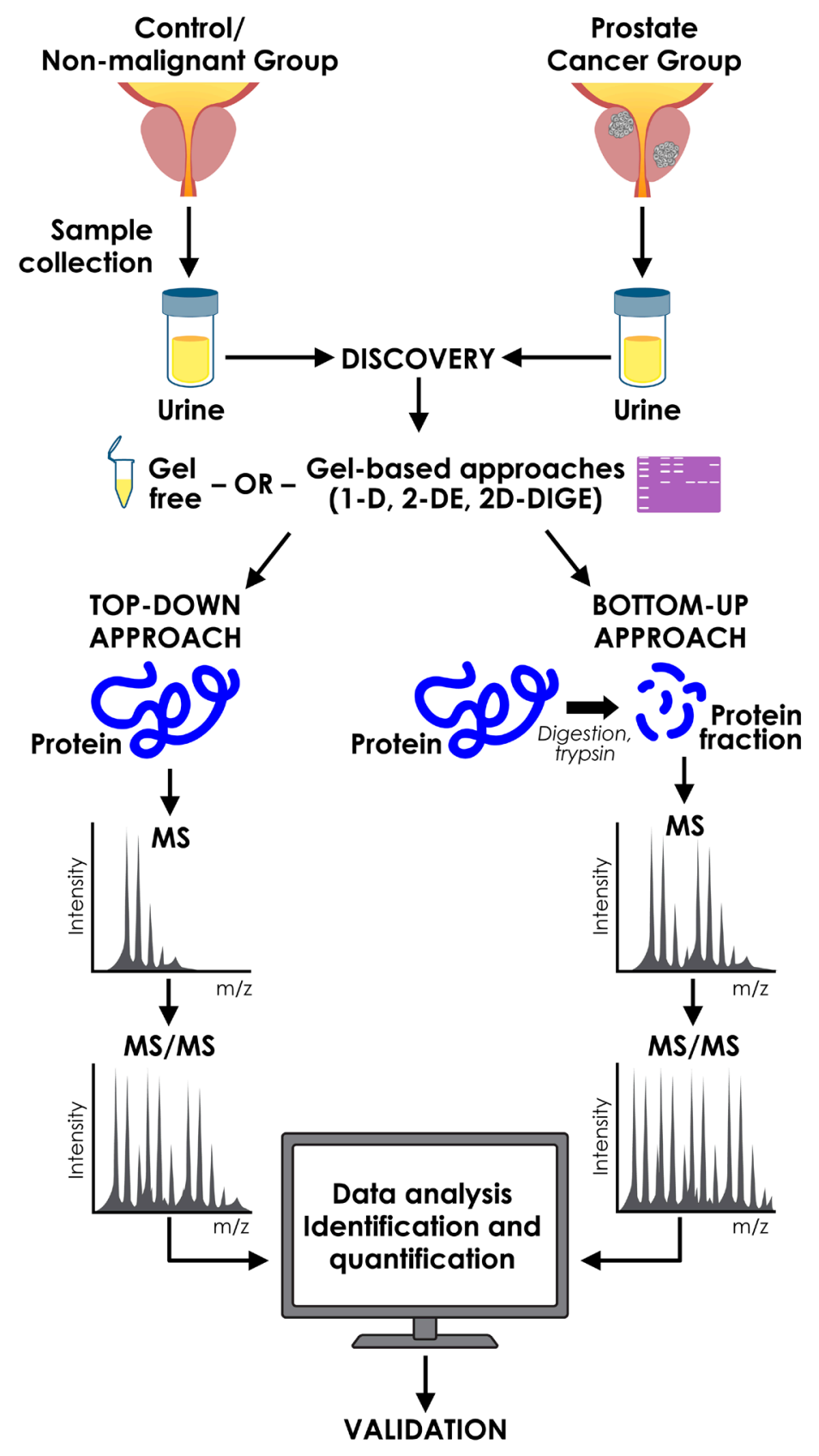

Figure 1: Proteomic approaches used in discovery of urinary prostate cancer biomarkers. 
for cancer diagnosis and prognosis as well as to monitor therapeutic responses in patients [33]. In particular, expression and activity of gelatinases, MMP-2 (72 kDa) and MMP-9 (92 kDa) have been shown to be significantly up-regulated in a variety of cancers, including prostate cancer. A sensitive and inexpensive method for analysis of gelatinases (MMPs) is gelatin zymography, which allows simultaneous measurement of both active and latent forms of MMP-2 and MMP-9 in biological fluids, including urine [89]. Our group used gelatin zymography to analyze urine samples from patients with organ-confined prostate cancer and samples with organ-confined bladder cancer as well as samples from control subjects. We found that MMP-9 dimer and MMP-9 were independent predictors for distinguishing between patients with prostate and bladder cancer $(\mathrm{P}<0.001$ for each). This study indicates that a tumor-specific urinary MMP fingerprint may noninvasively facilitate identification of cancer presence and type [47]. In another study, we have successfully used gelatin zymography to noninvasively monitor therapeutic efficacy in prostate cancer. Urinary MMPs were analyzed at the patient's first evaluation, during radiation treatment and after the radiation therapy. We found that urinary MMP levels were higher in patients with local-regional cancer compared with normal controls. Moreover, MMP levels were significantly higher $(P<0.001)$ in patients with metastatic disease at presentation than in patients with local-regional disease or normal controls $(P<0.001)$. The MMP levels were also significantly associated with 1 -year progression-free survival as was the individual MMP2 trend ( $P=0.004$ and 0.001 , respectively) [90]. These results were similar to our previously published data which found an increased incidence of urinary MMPs in cancer patients, including prostate cancer [91]. In summary, these data suggest that MMPs analyzed by gelatin zymography may play an important role in monitoring disease progression after radiotherapy and may also predict patient survival after therapy [90]. Recently, new noninvasive FRET (Förster resonance energy transfer)-based ratio-metric detection of hyaluronidase as a biomarker for bladder and prostate cancer has been reported. This assay uses a fluorescent substrate (termed HA-FRET) labeled with fluorescein as a donor and rhodamine as an acceptor for detection of enzymatic activity in synthetic urine. Digestion of the HA-FRET probe is measured with different concentrations of hyaluronidase via fluorescence emission and the extent to which FRET is released is dependent on the concentration of hyaluronidase [92].

Activity-based protein profiling (ABPP) has recently developed as an unconventional approach that is complementary to gene expression analysis and represents a tool to assist in decoding the overflow of genomic information [93]. Selective visualization of the active forms of specific enzymes by chemical probes termed activitybased probes (ABPs) is the ultimate goal of ABPP [94].
In contrast to substrate-based probes, ABPs covalently label the active site of a specific enzyme [95]. In general, ABPs consist of a reactive group for the covalent binding to the enzyme, a linker (spacer) for modulating reactivity and specificity of the reactive group and a reporter tag for characterization and purification of modified enzymes [96]. Detection of reporter tags can be done by various analytical platforms, including mass spectrometry, SDSPAGE, fluorescence microscopy, and in vivo imaging [95]. ABPs have been successfully developed for various proteases, including serine hydrolases, cysteine proteases, metallohydrolases, aspartyl proteases and the proteasome [97]. Recently, activity-based protein profiling-guided medicinal chemistry has been used for the discovery and development of the highly potent and selective inhibitor of serine hydrolase KIAA1363 in prostate cancer cell lines [98]. Moreover, activity-based protein profiling was also used to identify platelet activating factor acetylhydrolase $1 \mathrm{~B} 2$ and 1B3 (PAFAH1B2 and PAFAH1B3) which were consistently upregulated by various human oncogenes. Pharmacological blockade of PAFAH1B2 and PAFAH1B3 impaired cancer pathogenicity across a number of different types of cancer cells, including prostate cancer [99]. Lastly, activity-based proteomics (ABPP) used for carcinoma enzyme activity profiles may be more clinically valuable than expression-based proteomics for certain cancers, including prostate cancer [100]. Therefore, the application of ABPP techniques offers a versatile tool in liquid biopsy approaches for protein biomarker discovery and the development of highly potent and selective inhibitors.

\section{Data analysis and bioinformatics}

Bioinformatics plays a key role in the analysis of MS data [101] used to identify candidate biomarkers. Proteomic experiments often generate large datasets with massive amount of data [102] which need to be reduced into a short list of proteins. This represents challenge to accurately interpreting data and identifying candidate biomarkers. Therefore, functional annotation analysis of protein datasets through computational tools is critical for interpreting the results of high-throughput proteomics [102]. Pathway analysis may be applied to proteomic data to narrow down interesting biomarkers. Some of the most common tools used in pathway analysis are Ingenuity Pathway Analysis [103], KEGG [104] and MetaCORE [105]. We have also used Ingenuity Pathway Analysis (IPA) to determine differentially expressed pathways and functions in localized prostate cancer (PCa) as compared to BPH. IPA identified proteins in a number of different functional categories including cell assembly and organization, cell signaling, cell morphology, carbohydrate metabolism, cellular growth and proliferation, lipid metabolism, androgen and estrogen metabolism, and DNA replication, recombination and repair, among others. 
Additionally, network analysis identified differences in many focus hubs (e.g. NFאB, ERK1/2, Collagen, TGF $\beta$, PI3K, and p38 MAPK) with a high degree of interactivity. Furthermore, gene ontology tools are very valuable for better understanding the potential biological function and molecular process of a given protein [102]. A number of online gene ontology tools perform these analyses including, DAVID [106], BiNGO [107] and AmiGO [108]. In addition, interaction networks tools are essential in the visualization and interpretation of biological processes [102]. For instance, STRING [109] and Cytoscape [110] are some of the widely used interaction network software. Literature or text mining is another valuable informatics approach that can be useful in biomarker discovery. Several text-mining tools are available such as iHOP [111], Chilibot [112] and Biotext search engine [113]. Moreover, public availability of proteomics data from existing data repositories greatly assist researchers as they interpret their proteomics data and can significantly contribute to the generation of new hypotheses [102]. Recently, the ProteomeXchange (PX) consortium containing several member databases, including PRIDE and PeptideAtlas has been developed to enable better integration of public repositories and the coordinated sharing of proteomics information, maximizing its benefit to the scientific community [114].

\section{VALIDATION OF CANDIDATE BIOMARKERS}

The biomarker validation stage is a necessary requirement indispensable for successful biomarker implementation in clinical practice [115]. Only the most promising biomarkers that were previously verified should be considered for the evaluation. Moreover, the validation phase should include prospective and retrospective validation for general population screening [45]. Validation must be executed in an independent, appropriately large sample set that reflects the heterogeneity of the targeted population [116]. ELISA (enzyme-linked immunosorbent assay), immunoblot, protein arrays, immunohistochemistry (IHC), quantitative MS for protein and peptide analysis, and chemoproteomic assays are the most frequently used methods for protein biomarker validation [33]. However, only certain of these methods can be applied for validation of urinary biomarkers. Currently, due to its high throughput, high specificity, simplicity and high sensitivity for quantification of proteins, ELISA is considered to be the gold standard technique for validation of protein biomarkers [117] in biofluids, including urine. There remain several drawbacks regarding ELISA use in large validation studies including a limitation in the detection of a single antigen low-dynamic range, high cost of ELISA development and lack of specific antibodies [116]. Multiplex immunoassays have been developed to tackle some of the limitations of classical single-antigen based detection ELISA assays, including Assay platforms MULTI-ARRAY (Meso Scale Discovery), Bio-Plex (Bio-Rad Laboratories), A² (Beckman Coulter), FAST Quant (Whatman Schleicher \& Schuell BioScience), and FlowCytomix (Bender MedSystems) among others [118]. In particular, electrochemoluminiscence multiplex assay platforms offered by Meso Scale Discovery (MSD) are now being used for validation of non-invasive biomarkers [119] and clinically as well [120]. The MSD system consists of carbon electrode plates, which are pre-coated with captured antibodies against different targets at the bottom of each well. When the analyte, is applied it binds to the capture antibody followed by recognition of detection antibodies conjugated with electrochemiluminescent labels (SULFO-TAG) leading to light emission when the electricity is applied to the plates. MSD platforms come in 96- and 384-well formats, allowing quantification of 4,7 or 10 analytes per well in a 96-well format and single or 4 analytes in 384-well format. This system permits high throughput and measurement of multiple targets with broad dynamic range, high sensitivity, low background, ease of use, high performance and compatibility with biofluids. The sample volume required is only $25 \mathrm{ul} /$ well for the 96 -well and $10 \mathrm{ul} /$ well for the 384 -well format, thus being suitable for analysis of small volume samples [121]. Recently, the multiplex proximity ligation assay (PLA) has gained increased clinical attention with respect to predicting severity of disease [122]. The PLA method is based on the ability of two or more antibodies to recognize targeted proteins by using DNA oligonucleotides bound to conjugated antibodies which can be then hybridized to form single DNA strands through ligation or polymerization [123]. Quantification is then performed by RT-PCR or by DNA sequencing. The 4-PLA (4 distinct antibodies) approach was used to investigate prostasomes (microvesicles from prostate cancer cells) as promising plasma biomarkers for $\mathrm{PCa}$. The results revealed significantly elevated levels of prostasomes in blood of PCa patients compared to controls or patients diagnosed with benign disease. Moreover, the assay was able to differentiate patients with medium (7) or high Gleason score (8/9) from patients with low Gleason score $(\leq 6)$, thus mirroring prostate cancer aggressiveness. This study suggests that the PLA method may represent a useful tool for assessment and prognosis of localized PCa [124]. Another commonly used method to validate urinary protein biomarkers is western blot (immunoblot) analysis. However, this approach can be used only on small cohorts due to its limitations regarding detection of single antigens, the requirement to optimize experimental conditions, labor intensity, lack of specific antibodies and lack of high-throughput capacity among other limitations. Nevertheless, these 
Table 1: Urinary biomarkers for prostate cancer

\begin{tabular}{|c|c|c|c|}
\hline Urinary Biomarker & Method & Results & References \\
\hline Transferrin & Immunoturbidimetric assay & $\begin{array}{l}\text { Significantly increased levels in } 18 \text { out of } \\
22 \mathrm{PCa} \text { patients }\end{array}$ & {$[137]$} \\
\hline uTF & Chromogenic assay & Sen. $68 \%$, Spe. $75 \%$ & [138] \\
\hline MCM-5 & Immunofluorometric assay & $\begin{array}{c}\text { Higher levels of Mcm5 in their urine } \\
\text { sediments than did men without } \\
\text { malignancy }(P<.001)\end{array}$ & [139] \\
\hline AMACR & Western blot & Sen. $100 \%$, Spe $58 \%$ & {$[140]$} \\
\hline Calgranulin B/MRP-14 & 2D-PAGE, MALDI-TOF-MS & $\begin{array}{l}\text { Present in four of six fluid samples from } \\
\text { patients with cancer but in none of the } \\
\text { fluid samples from patients with BPH }\end{array}$ & {$[75]$} \\
\hline TB-15 & ELISA & Sen. $41 \%$, Spe. $92 \%$ & {$[141]$} \\
\hline $\begin{array}{l}\text { Uromodulin, semenogelin } \\
\text { I isoform b preproprotein }\end{array}$ & MALDI-TOF & Sen. $71 \%$, Spe. $67 \%$ & {$[142]$} \\
\hline MMP species & Gelatin zymography, MS & Sen. $74 \%$, Spe. $82 \%$ & {$[47]$} \\
\hline 12 protein panel & CE-MS & Sen. $89 \%$, Spe. $51 \%$ & [131] \\
\hline ANXA3 & Western blot & $\mathrm{AUC}=0.687$ & {$[143]$} \\
\hline CD105 & ELISA & $\mathrm{AUC}=0.72$ & {$[144]$} \\
\hline CD90/Thy-1 & ICAT labeling, LC-MS/MS & Elevated in urine of $\mathrm{PCa}$ patients & {$[145]$} \\
\hline CD14 & MALDI-TOF, nanoLC-ESI-MS/MS & Spe. $84-100 \%$ & {$[146]$} \\
\hline EN2 & ELISA & Sen. $66 \%$, Spe. $88 \%$ & {$[147]$} \\
\hline ZAG & Western blot & $\mathrm{AUC}=0.68$ & {$[148]$} \\
\hline Fibronectin & LC-MS/MS, qRT-PCR & Sen. $75 \%$, Spe. $50 \%$ & {$[149]$} \\
\hline HP, AMBP & 2-D DIGE, MALDI-MS, IPA analysis & $\mathrm{HP}, \mathrm{AUC}=0.723 ; \mathrm{AMBP}, \mathrm{AUC}=0.738$ & {$[150]$} \\
\hline UGM & N-glycosylation profiling & $\mathrm{AUC}=0.71$ & {$[151]$} \\
\hline B2M, PGA3, MUC3 & iTRAQ, Western blot & $\mathrm{AUC}=0.81(3$ proteins + PSA $)$ & {$[5]$} \\
\hline PSA glycoform & LC-MS & Sen. $87.5 \%$, Spe. $60 \%$ & {$[152]$} \\
\hline
\end{tabular}

Abbreviations: AUC, area under the curve; Sen., sensitivity; Spe., specificity; uTF, tissue factor in urine; AMACR, $\alpha$-methylacyl-CoA racemase; MCM5, minichromosome maintenance 5 protein; TB-15, thymosin $\beta$ - 15 ; MMP, matrix metalloproteinases; ANXA3, annexin A3; CD105, endoglin; CD90/Thy-1, cluster of differentiation 90; CD14, cluster of differentiation 14; EN2, engrailed-2; ZAG, zinc $\alpha 2$-glygoprotein; HP, haptoglobin; AMBP, $\alpha$-1-microglobulin/bikunin precursor; UGM, urinary glycoprofile marker; $\beta 2 \mathrm{M}, \beta$-2-microglobulin; PGA3, pepsinogen 3, group 1; MUC3, intestinal mucin 3; PSA, prostate specific antigen.

two conventional methods (ELISA and western blot), are often the first choice for validation of biomarkers [49]. Promising alternatives to the immunoassays discussed above are MS-based targeted approaches offering reduced costs, shortened lead-time, and greatly improved throughput [44]. Selected reaction monitoring (SRM) and multiple-reaction monitoring (MRM) are the two most common methods used for absolute quantification of proteins in combination with stable isotope dilution [49]. However, these methods also have some shortcomings that include limited commercial availability of isotopically labeled internal standards and high cost. The recent implementation of targeted highresolution and accurate-mass analyses on fast sequencing mass spectrometers operated in parallel reaction monitoring (PRM) mode offers a clear improvement over the classical SRM/MRM measurements performed on triple quadrupole instruments $[53,55]$. In addition, compared to SRM/MRM methods it provides improved selectivity, specificity, superior resolving power and better discrimination of the signal of the analytes from that of the matrix $[53,55]$. In the future, the versatility of 
the MS-based targeted approaches may prove to be more cost-effective and less time-consuming than immunobased approaches for urinary biomarker validation.

\section{NONINVASIVE URINE-BASED PROSTATE CANCER BIOMARKERS}

Recent advances in proteomic technologies, molecular biology and better understanding of carcinogenesis with respect to $\mathrm{PCa}$ has led to the discovery of new protein biomarkers [11] and to innovations in liquid biopsy approaches. Protein-based biomarkers are frequently secreted into bodily fluids, including urine, and in contrast to DNA and RNA do not necessarily rely on the presence of cancer cells for detection [125]. In addition, nucleic acid-based markers are limited in their ability to integrate information associated with the downstream processing of proteins significantly affecting the information content of a biomarker [126]. The ideal biomarker should be highly sensitive, specific to $\mathrm{PCa}$, not altered or expressed in other human tissues or diseases and the method of collection should be non-invasive. It is well accepted that every single biomarker has its own performance limits. Therefore, a panel of biomarkers, rather than single biomarker in isolation, could improve accuracy, decrease false positive values and better address the complexity of the disease. In addition, certain biomarkers may work better together than in isolation. Our longstanding interest has been to identify noninvasive diagnostic and prognostic biomarkers for variety of cancers, including prostate cancer [33]. The list of discovered urinary protein biomarkers including biomarkers discovered by us is summarized in Table 1. The summary exclusively focuses on proteins and does not include RNA, DNA, metabolomics, exosome or cancer cell-based biomarkers which are beyond the scope of this article. There are a number of novel emerging PCa biomarkers that should be noted. Recently, there has been an increase in interest of some tissue-based biomarkers for PCa including PTEN, ERG, FASN, MAGI-2, SPINK1 [127], CXCL12 [128] and glycoforms of PSA present in blood [129]. The alternatives to more traditional tissuebased or blood-based biomarkers are biomarkers present in human urine. The best known/studied emerging urinary biomarkers include aHGF, IGFBP3 [130] and OPN [130, 131], long non-coding RNA (lncRNA) biomarkers such as PCA-3, TMPRSS2, and PCa specific methylation biomarkers such as glutathione S-transferase P (GSTP1) [132]. In addition, circulating tumor cells (CTC), exosomes, cell-free DNA (cfDNA) and miRNAs [129] including miR-100/200b [133], miR-21 and miR-375 [134] have been reported and show promise as prostate cancer biomarkers. Currently, a few non-protein based urinary tests for prostate cancer are commercially available including PCA3 (Hologic, Marlborough, MA, USA), TMPRSS2:ERG (University of Michigan, MI, USA),
ExoDx (Exosome Diagnostics Inc., Cambridge, MA, USA), SChLAP1 (GenomeDx Biosciences, San Diego, CA, USA) and SelectMDx (MDxHealth, Irvine, CA, USA) [6]. There are, to our knowledge, few if any protein-based non-invasive FDA approved and commercially available, reliable urinary tests for prostate cancer. Therefore, there is an unmet need and unique opportunity for the development of a non-invasive urinary protein-based test which can detect PCa with high sensitivity and specificity.

\section{CONCLUSIONS}

Urine is an ideal body fluid and liquid biopsy resource for the identification and measurement of protein biomarkers [24] for prostate cancer, permitting easy, non-invasive sample collection. Urine based biomarkers offer the potential for home testing which would facilitate diagnosis and monitoring of prostate cancer patients. In addition, urinary protein biomarkers might also reflect phenotypic cellular changes of malignancy and complement or surpass biomarkers [135] from other biofluids or tissues. Genomic studies could also be enhanced by urinary protein biomarker findings thus improving the management of prostate cancer including earlier diagnosis and selection of best treatment, ultimately leading to improved outcomes [24]. Novel and accurate biomarkers could also help to identify patients who can benefit from follow-up on an active surveillance program for low-risk PCa [136]. However, current development of urinary protein biomarkers for $\mathrm{PCa}$ is facing numerous limitations and challenges. Most of the published studies are retrospective, use different biopsy and urine collection protocols, vary in study design and population characteristics and utilize arbitrary definitions of clinical significance and disease progression. There is also limited information regarding to intermediate endpoints and missing data with respect to long-term readouts such as time to metastasis or prostate cancer-specific mortality [136].

\section{ACKNOWLEDGMENTS AND FUNDING}

The authors are grateful to the Ellison Foundation for their support. Kristin Johnson of the Vascular Biology Program is acknowledged for her graphic support.

\section{CONFLICTS OF INTEREST}

None.

\section{REFERENCES}

1. Siegel RL, Miller KD, Jemal A. Cancer Statistics, 2017. CA Cancer J Clin. 2017; 67:7-30. https://doi.org/10.3322/caac.21387. 
2. DeSantis CE, Lin CC, Mariotto AB, Siegel RL, Stein KD, Kramer JL, Alteri R, Robbins AS, Jemal A. Cancer treatment and survivorship statistics, 2014. CA Cancer J Clin. 2014; 64:252-71. https://doi.org/10.3322/caac.21235.

3. Sinnott JA, Rider JR, Carlsson J, Gerke T, Tyekucheva S, Penney KL, Sesso HD, Loda M, Fall K, Stampfer MJ, Mucci LA, Pawitan Y, Andersson SO, Andrén O. Molecular differences in transition zone and peripheral zone prostate tumors. Carcinogenesis. 2015; 36:632-38. https://doi.org/10.1093/carcin/bgv051.

4. Tonry CL, Leacy E, Raso C, Finn SP, Armstrong J, Pennington SR. The role of proteomics in biomarker development for improved patient diagnosis and clinical decision making in prostate cancer. Diagnostics (Basel). 2016; 6:E27. https://doi.org/10.3390/diagnostics6030027.

5. Jedinak A, Curatolo A, Zurakowski D, Dillon S, Bhasin MK, Libermann TA, Roy R, Sachdev M, Loughlin KR, Moses MA. Novel non-invasive biomarkers that distinguish between benign prostate hyperplasia and prostate cancer. BMC Cancer. 2015; 15:259. https://doi.org/10.1186/s12885-015-1284-z.

6. McGrath S, Christidis D, Perera M, Hong SK, Manning T, Vela I, Lawrentschuk N. Prostate cancer biomarkers: are we hitting the mark? Prostate Int. 2016; 4:130 35. https://doi.org/10.1016/j.prnil.2016.07.002.

7. Behesnilian AS, Reiter RE. Risk stratification of prostate cancer in the modern era. Curr Opin Urol. 2015; 25:246-51. https://doi.org/10.1097/MOU.0000000000000164.

8. Andriole GL, Crawford ED, Grubb RL 3rd, Buys SS, Chia D, Church TR, Fouad MN, Gelmann EP, Kvale PA, Reding DJ, Weissfeld JL, Yokochi LA, O’Brien B, et al, and PLCO Project Team. Mortality results from a randomized prostatecancer screening trial. N Engl J Med. 2009; 360:1310-19. https://doi.org/10.1056/NEJMoa0810696.

9. Shariat SF, Roehrborn CG. Using biopsy to detect prostate cancer. Rev Urol. 2008; 10:262-80.

10. Sohn E. Screening: diagnostic dilemma. Nature. 2015; 528:S120-22. https://doi.org/10.1038/528S120a.

11. Hendriks RJ, van Oort IM, Schalken JA. Blood-based and urinary prostate cancer biomarkers: a review and comparison of novel biomarkers for detection and treatment decisions. Prostate Cancer Prostatic Dis. 2017; 20:12-19. https://doi.org/10.1038/pcan.2016.59.

12. Wang MC, Valenzuela LA, Murphy GP, Chu TM. Purification of a human prostate specific antigen. Invest Urol. 1979; 17:159-63.

13. Papsidero LD, Wang MC, Valenzuela LA, Murphy GP, Chu TM. A prostate antigen in sera of prostatic cancer patients. Cancer Res. 1980; 40:2428-32.

14. Stephan C, Jung K, Ralla B. Current biomarkers for diagnosing of prostate cancer. Future Oncol. 2015; 11:2743-55. https://doi.org/10.2217/fon.15.203.

15. Polascik TJ, Oesterling JE, Partin AW. Prostate specific antigen: a decade of discovery - what we have learned and where we are going. J Urol. 1999; 162:293-306. https://doi.org/10.1016/S0022-5347(05)68543-6.
16. Frazier HA, Humphrey PA, Burchette JL, Paulson DF. Immunoreactive prostatic specific antigen in male periurethral glands. J Urol. 1992; 147:246-48. https://doi.org/10.1016/S0022-5347(17)37206-3.

17. Levesque M, Hu H, D'Costa M, Diamandis EP. Prostatespecific antigen expression by various tumors. J Clin Lab Anal. 1995; 9:123-28. https://doi.org/10.1002/jcla.1860090209.

18. Draisma G, Etzioni R, Tsodikov A, Mariotto A, Wever E, Gulati R, Feuer E, de Koning H. Lead time and overdiagnosis in prostate-specific antigen screening: importance of methods and context. J Natl Cancer Inst. 2009; 101:374-83. https://doi.org/10.1093/jnci/djp001.

19. Salagierski M, Schalken JA. Molecular diagnosis of prostate cancer: PCA3 and TMPRSS2:ERG gene fusion. J Urol. 2012; 187:795-801. https://doi.org/10.1016/j.juro.2011.10.133.

20. Thompson IM, Pauler DK, Goodman PJ, Tangen CM, Lucia MS, Parnes HL, Minasian LM, Ford LG, Lippman SM, Crawford ED, Crowley JJ, Coltman CA Jr. Prevalence of prostate cancer among men with a prostate-specific antigen level $<$ or $=4.0 \mathrm{ng}$ per milliliter. N Engl J Med. 2004; 350:2239-46. https://doi.org/10.1056/NEJMoa031918.

21. Greene KL, Albertsen PC, Babaian RJ, Carter HB, Gann PH, Han M, Kuban DA, Sartor AO, Stanford JL, Zietman A, Carroll P. Prostate specific antigen best practice statement: 2009 update. J Urol. 2009; 182:2232-41. https://doi.org/10.1016/j.juro.2009.07.093.

22. Prostate Cancer: Screening. U.S. Preventive Services Task Force. Available from https://www. uspreventiveservicestaskforce.org/Page/Document/ UpdateSummaryFinal/prostate-cancer-screening.

23. Sauerbrei W, Taube SE, McShane LM, Cavenagh MM, Altman DG. Reporting recommendations for tumor marker prognostic studies (REMARK): an abridged explanation and elaboration. J Natl Cancer Inst. 2018; djy088. https://doi.org/10.1093/jnci/djy088.

24. Wood SL, Knowles MA, Thompson D, Selby PJ, Banks RE. Proteomic studies of urinary biomarkers for prostate, bladder and kidney cancers. Nat Rev Urol. 2013; 10:20618. https://doi.org/10.1038/nrurol.2013.24.

25. Adachi J, Kumar C, Zhang Y, Olsen JV, Mann M. The human urinary proteome contains more than 1500 proteins, including a large proportion of membrane proteins. Genome Biol. 2006; 7:R80. https://doi.org/10.1186/gb-2006-7-9-r80.

26. Kalantari S, Jafari A, Moradpoor R, Ghasemi E, Khalkhal E. Human urine proteomics: analytical techniques and clinical applications in renal diseases. Int J Proteomics. 2015; 2015:782798. https://doi.org/10.1155/2015/782798.

27. Zhao M, Li M, Yang Y, Guo Z, Sun Y, Shao C, Li M, Sun W, Gao Y. A comprehensive analysis and annotation of human normal urinary proteome. Sci Rep. 2017; 7:3024. https://doi.org/10.1038/s41598-017-03226-6.

28. Ponomarenko EA, Poverennaya EV, Ilgisonis EV, Pyatnitskiy MA, Kopylov AT, Zgoda VG, Lisitsa AV, Archakov AI. The size of the human proteome: the 
width and depth. Int J Anal Chem. 2016; 2016:7436849. https://doi.org/10.1155/2016/7436849.

29. Strong KJ, Osicka TM, Comper WD. Urinarypeptide excretion by patients with and volunteers without diabetes. J Lab Clin Med. 2005; 145:239-46. https://doi.org/10.1016/j.lab.2004.11.021.

30. Filip S, Vougas K, Zoidakis J, Latosinska A, Mullen W, Spasovski G, Mischak H, Vlahou A, Jankowski J. Comparison of Depletion Strategies for the Enrichment of Low-Abundance Proteins in Urine. PLoS One. 2015; 10:e0133773. https://doi.org/10.1371/journal.pone.0133773.

31. Nevedomskaya E, Ramautar R, Derks R, Westbroek I, Zondag G, van der Pluijm I, Deelder AM, Mayboroda OA. CE-MS for metabolic profiling of volume-limited urine samples: application to accelerated aging TTD mice. J Proteome Res. 2010; 9:4869-74. https://doi.org/10.1021/pr100634d.

32. Theodorescu D, Mischak H. Mass spectrometry based proteomics in urine biomarker discovery. World J Urol. 2007; 25:435-43. https://doi.org/10.1007/s00345-007-0206-3.

33. Yang J, Roy R, Jedinak A, Moses MA. Mining the human proteome: biomarker discovery for human cancer and metastases. Cancer J. 2015; 21:327-36. https://doi.org/10.1097/PPO.0000000000000139.

34. Zhang $\mathrm{Z}, \mathrm{Wu} \mathrm{S}$, Stenoien DL, Paša-Tolić L. High-throughput proteomics. Annu Rev Anal Chem (Palo Alto, Calif). 2014; 7:427-54. https://doi.org/10.1146/annurev-anchem-071213-020216.

35. Zhang Y, Fonslow BR, Shan B, Baek MC, Yates JR 3rd. Protein analysis by shotgun/bottom-up proteomics. Chem Rev. 2013; 113:2343-94. https://doi.org/10.1021/cr3003533.

36. Tsiatsiani L, Heck AJ. Proteomics beyond trypsin. FEBS J. 2015; 282:2612-26. https://doi.org/10.1111/febs.13287.

37. Gregorich ZR, Ge Y. Top-down proteomics in health and disease: challenges and opportunities. Proteomics. 2014; 14:1195-210. https://doi.org/10.1002/pmic.201300432.

38. Altelaar AF, Munoz J, Heck AJ. Next-generation proteomics: towards an integrative view of proteome dynamics. Nat Rev Genet. 2013; 14:35-48. https://doi.org/10.1038/nrg3356.

39. Mann M, Jensen ON. Proteomic analysis of posttranslational modifications. Nat Biotechnol. 2003; $21: 255$ 61. https://doi.org/10.1038/nbt0303-255.

40. Karve TM, Cheema AK. Small changes huge impact: the role of protein posttranslational modifications in cellular homeostasis and disease. J Amino Acids. 2011; 2011:207691. https://doi.org/10.4061/2011/207691.

41. Schiffer E, Mischak H, Theodorescu D, Vlahou A. Challenges of using mass spectrometry as a bladder cancer biomarker discovery platform. World J Urol. 2008; 26:6774. https://doi.org/10.1007/s00345-007-0234-z.

42. Boeri Erba E. Investigating macromolecular complexes using top-down mass spectrometry. Proteomics. 2014; 14:1259-70. https://doi.org/10.1002/pmic.201300333.
43. Wu CC, MacCoss MJ. Shotgun proteomics: tools for the analysis of complex biological systems. Curr Opin Mol Ther. 2002; 4:242-50.

44. Thomas S, Hao L, Ricke WA, Li L. Biomarker discovery in mass spectrometry-based urinary proteomics. Proteomics Clin Appl. 2016; 10:358-70. https://doi.org/10.1002/prca.201500102.

45. Drabovich AP, Martínez-Morillo E, Diamandis EP. Toward an integrated pipeline for protein biomarker development. Biochim Biophys Acta. 2015; 1854:677-86. https://doi.org/10.1016/j.bbapap.2014.09.006.

46. Pan S, Brentnall TA, Kelly K, Chen R. Tissue proteomics in pancreatic cancer study: discovery, emerging technologies, and challenges. Proteomics. 2013; 13:710-21. https://doi.org/10.1002/pmic.201200319.

47. Roy R, Louis G, Loughlin KR, Wiederschain D, Kilroy SM, Lamb CC, Zurakowski D, Moses MA. Tumorspecific urinary matrix metalloproteinase fingerprinting: identification of high molecular weight urinary matrix metalloproteinase species. Clin Cancer Res. 2008; 14:661017. https://doi.org/10.1158/1078-0432.CCR-08-1136.

48. Sandin M, Chawade A, Levander F. Is label-free LC-MS/ MS ready for biomarker discovery? Proteomics Clin Appl. 2015; 9:289-94. https://doi.org/10.1002/prca.201400202.

49. Jerebtsova M, Nekhai S. Quantitative mass spectrometry of urinary biomarkers. J Integr OMICS. 2014; 4:69-78. https://doi.org/10.5584/jiomics.v4i2.177.

50. Sajic T, Liu Y, Aebersold R. Using data-independent, highresolution mass spectrometry in protein biomarker research: perspectives and clinical applications. Proteomics Clin Appl. 2015; 9:307-21. https://doi.org/10.1002/prca.201400117.

51. Heegaard NH, Østergaard O, Bahl JM, Overgaard M, Beck HC, Rasmussen LM, Larsen MR. Important options available - from start to finish - for translating proteomics results to clinical chemistry. Proteomics Clin Appl. 2015; 9:235-52. https://doi.org/10.1002/prca.201400137.

52. Scherl A. Clinical protein mass spectrometry. Methods. 2015; 81:3-14. https://doi.org/10.1016/j.ymeth.2015.02.015.

53. Gallien S, Domon B. Advances in high-resolution quantitative proteomics: implications for clinical applications. Expert Rev Proteomics. 2015; 12:489-98. https://doi.org/10.1586/14789450.2015.1069188.

54. Lesur A, Domon B. Advances in high-resolution accurate mass spectrometry application to targeted proteomics. Proteomics. 2015; 15:880-90. https://doi.org/10.1002/pmic.201400450.

55. Bourmaud A, Gallien S, Domon B. Parallel reaction monitoring using quadrupole-Orbitrap mass spectrometer: principle and applications. Proteomics. 2016; 16:2146-59. https://doi.org/10.1002/pmic.201500543.

56. Perez-Riverol Y, Wang R, Hermjakob H, Müller M, Vesada V, Vizcaíno JA. Open source libraries and frameworks for mass spectrometry based proteomics: a developer's perspective. Biochim Biophys Acta. 2014; 1844:63-76. https://doi.org/10.1016/j.bbapap.2013.02.032. 
57. Eng JK, McCormack AL, Yates JR. An approach to correlate tandem mass spectral data of peptides with amino acid sequences in a protein database. J Am Soc Mass Spectrom. 1994; 5:976-89. https://doi.org/10.1016/1044-0305(94)80016-2.

58. Craig R, Beavis RC. TANDEM: matching proteins with tandem mass spectra. Bioinformatics. 2004; 20:1466-67. https://doi.org/10.1093/bioinformatics/bth092.

59. Perkins DN, Pappin DJ, Creasy DM, Cottrell JS. Probability-based protein identification by searching sequence databases using mass spectrometry data. Electrophoresis. 1999; 20:3551-67. https://doi.org/10.1002/ (SICI)1522-2683(19991201)20:18<3551::AIDELPS3551>3.0.CO;2-2.

60. Tabb DL, Fernando CG, Chambers MC. MyriMatch: highly accurate tandem mass spectral peptide identification by multivariate hypergeometric analysis. J Proteome Res. 2007; 6:654-61. https://doi.org/10.1021/pr0604054.

61. Cox J, Neuhauser N, Michalski A, Scheltema RA, Olsen JV, Mann M. Andromeda: a peptide search engine integrated into the MaxQuant environment. J Proteome Res. 2011; 10:1794-805. https://doi.org/10.1021/pr101065j.

62. Wang $\mathrm{X}$, Zhang B. Integrating genomic, transcriptomic, and interactome data to improve Peptide and protein identification in shotgun proteomics. J Proteome Res. 2014; 13:2715-23. https://doi.org/10.1021/pr500194t.

63. Deutsch EW, Mendoza L, Shteynberg D, Slagel J, Sun Z, Moritz RL. Trans-Proteomic Pipeline, a standardized data processing pipeline for large-scale reproducible proteomics informatics. Proteomics Clin Appl. 2015; 9:745-54. https://doi.org/10.1002/prca.201400164.

64. Craig R, Cortens JP, Beavis RC. Open source system for analyzing, validating, and storing protein identification data. J Proteome Res. 2004; 3:1234-42. https://doi.org/10.1021/pr049882h.

65. Farrah T, Deutsch EW, Omenn GS, Sun Z, Watts JD, Yamamoto T, Shteynberg D, Harris MM, Moritz RL. State of the human proteome in 2013 as viewed through PeptideAtlas: comparing the kidney, urine, and plasma proteomes for the biology- and disease-driven Human Proteome Project. J Proteome Res. 2014; 13:60-75. https://doi.org/10.1021/pr4010037.

66. Vizcaíno JA, Côté RG, Csordas A, Dianes JA, Fabregat A, Foster JM, Griss J, Alpi E, Birim M, Contell J, O'Kelly G, Schoenegger A, Ovelleiro D, et al. The PRoteomics IDEntifications (PRIDE) database and associated tools: status in 2013. Nucleic Acids Res. 2013; 41:D1063-69. https://doi.org/10.1093/nar/gks1262.

67. Zhang Y, Zhang Y, Adachi J, Olsen JV, Shi R, de Souza G, Pasini E, Foster LJ, Macek B, Zougman A, Kumar C, Wisniewski JR, Jun W, Mann M. MAPU: Max-Planck Unified database of organellar, cellular, tissue and body fluid proteomes. Nucleic Acids Res. 2007; 35:D771-79. https://doi.org/10.1093/nar/gk1784.
68. Li SJ, Peng M, Li H, Liu BS, Wang C, Wu JR, Li YX, Zeng R. Sys-BodyFluid: a systematical database for human body fluid proteome research. Nucleic Acids Res. 2009; 37:D907-12. https://doi.org/10.1093/nar/gkn849.

69. Human Kidney and Urine Proteome Project. http://www.hkupp.org/.

70. Renal Epithelial Transcriptome and Proteome Databases. Kidney Systems Biology Project. National Heart Lung and Blood Institute. Available from https:/hpcwebapps.cit.nih.gov/ESBL/Database/index.html.

71. Shao C, Li M, Li X, Wei L, Zhu L, Yang F, Jia L, Mu Y, Wang J, Guo Z, Zhang D, Yin J, Wang Z, et al. A tool for biomarker discovery in the urinary proteome: a manually curated human and animal urine protein biomarker database. Mol Cell Proteomics. 2011; 10:M111.010975. https://doi.org/10.1074/mcp.M111.010975.

72. https://mosaiques-diagnostics.de/mosaiques-diagnostics/

73. Husi H, Barr JB, Skipworth RJ, Stephens NA, Greig CA, Wackerhage $\mathrm{H}$, Barron $\mathrm{R}$, Fearon $\mathrm{KC}$, Ross JA. The human urinary proteome fingerprint database UPdb. Int J Proteomics. 2013; 2013:760208. https://doi.org/10.1155/2013/760208.

74. Filip S, Zoidakis J, Vlahou A, Mischak H. Advances in urinary proteome analysis and applications in systems biology. Bioanalysis. 2014; 6:2549-69. https://doi.org/10.4155/bio.14.210.

75. Rehman I, Azzouzi AR, Catto JW, Allen S, Cross SS, Feeley K, Meuth M, Hamdy FC. Proteomic analysis of voided urine after prostatic massage from patients with prostate cancer: a pilot study. Urology. 2004; 64:1238-43. https://doi.org/10.1016/j.urology.2004.06.063.

76. Latosinska A, Vougas K, Makridakis M, Klein J, Mullen W, Abbas M, Stravodimos K, Katafigiotis I, Merseburger AS, Zoidakis J, Mischak H, Vlahou A, Jankowski V. Comparative analysis of label-free and 8-plex iTRAQ approach for quantitative tissue proteomic analysis. PLoS One. 2015; 10:e0137048. https://doi.org/10.1371/journal.pone.0137048.

77. Wu WW, Wang G, Baek SJ, Shen RF. Comparative study of three proteomic quantitative methods, DIGE, cICAT, and iTRAQ, using 2D gel- or LC-MALDI TOF/TOF. J Proteome Res. 2006; 5:651-58. https://doi.org/10.1021/pr050405o.

78. Pottiez G, Wiederin J, Fox HS, Ciborowski P. Comparison of 4-plex to 8-plex iTRAQ quantitative measurements of proteins in human plasma samples. J Proteome Res. 2012; 11:3774-81. https://doi.org/10.1021/pr300414z.

79. Liu NQ, Dekker LJ, Stingl C, Güzel C, De Marchi T, Martens JW, Foekens JA, Luider TM, Umar A. Quantitative proteomic analysis of microdissected breast cancer tissues: comparison of label-free and SILAC-based quantification with shotgun, directed, and targeted MS approaches. J Proteome Res. 2013; 12:4627-41. https://doi.org/10.1021/pr4005794.

80. Megger DA, Pott LL, Ahrens M, Padden J, Bracht T, Kuhlmann K, Eisenacher M, Meyer HE, Sitek B. Comparison of label-free and label-based 
strategies for proteome analysis of hepatoma cell lines. Biochim Biophys Acta. 2014; 1844:967-76. https://doi.org/10.1016/j.bbapap.2013.07.017.

81. Schiffer E, Bick C, Grizelj B, Pietzker S, Schöfer W. Urinary proteome analysis for prostate cancer diagnosis: cost-effective application in routine clinical practice in Germany. Int J Urol. 2012; 19:118-25. https://doi.org/10.1111/j.1442-2042.2011.02901.x.

82. Dijkstra S, Govers TM, Hendriks RJ, Schalken JA, Van Criekinge W, Van Neste L, Grutters JP, Sedelaar JP, van Oort IM. Cost-effectiveness of a new urinary biomarkerbased risk score compared to standard of care in prostate cancer diagnostics - a decision analytical model. BJU Int. 2017; 120:659-65. https://doi.org/10.1111/bju.13861.

83. Heijnsdijk EA, Denham D, de Koning HJ. The costeffectiveness of prostate cancer detection with the use of prostate health index. Value Health. 2016; 19:153-57. https://doi.org/10.1016/j.jval.2015.12.002.

84. Padoan A, Basso D, La Malfa M, Zambon CF, Aiyetan P, Zhang H, Di Chiara A, Pavanello G, Bellocco R, Chan DW, Plebani M. Reproducibility in urine peptidome profiling using MALDI-TOF. Proteomics. 2015; 15:147685. https://doi.org/10.1002/pmic.201400253.

85. Chen CL, Lin TS, Tsai CH, Wu CC, Chung T, Chien KY, Wu M, Chang YS, Yu JS, Chen YT. Identification of potential bladder cancer markers in urine by abundant-protein depletion coupled with quantitative proteomics. J Proteomics. 2013; 85:28-43. https://doi.org/10.1016/j.jprot.2013.04.024.

86. Nagaraj N, Mann M. Quantitative analysis of the intra- and inter-individual variability of the normal urinary proteome. J Proteome Res. 2011; 10:637-45. https://doi.org/10.1021/pr100835s.

87. Fu Q, Grote E, Zhu J, Jelinek C, Köttgen A, Coresh J, Van Eyk JE. An empirical approach to signature peptide choice for selected reaction monitoring: quantification of uromodulin in urine. Clin Chem. 2016; 62:198-207. https://doi.org/10.1373/clinchem.2015.242495.

88. Jedinák A, Maliar T. Inhibitors of proteases as anticancer drugs. Neoplasma. 2005; 52:185-92.

89. Ricci S, D'Esposito V, Oriente F, Formisano P, Di Carlo A. Substrate-zymography: a still worthwhile method for gelatinases analysis in biological samples. Clin Chem Lab Med. 2016; 54:1281-90. https://doi.org/10.1515/cclm-2015-0668.

90. Chan LW, Moses MA, Goley E, Sproull M, Muanza T, Coleman CN, Figg WD, Albert PS, Ménard C, Camphausen $\mathrm{K}$. Urinary VEGF and MMP levels as predictive markers of 1-year progression-free survival in cancer patients treated with radiation therapy: a longitudinal study of protein kinetics throughout tumor progression and therapy. J Clin Oncol. 2004; 22:499-506. https://doi.org/10.1200/JCO.2004.07.022.

91. Moses MA, Wiederschain D, Loughlin KR, Zurakowski D, Lamb CC, Freeman MR. Increased incidence of matrix metalloproteinases in urine of cancer patients. Cancer Res. 1998; 58:1395-99.

92. Chib R, Raut S, Fudala R, Chang A, Mummert M, Rich R, Gryczynski Z, Gryczynski I. FRET based ratio-metric sensing of hyaluronidase in synthetic urine as a biomarker for bladder and prostate cancer. Curr Pharm Biotechnol. 2013; 14:470-74. https://doi.org/10.2174/13892010113149990222.

93. Yang P, Liu K. Activity-based protein profiling: recent advances in probe development and applications. ChemBioChem. 2015; 16:712-24. https://doi.org/10.1002/cbic.201402582.

94. Willems LI, Overkleeft HS, van Kasteren SI. Current developments in activity-based protein profiling. Bioconjug Chem. 2014; 25:1181-91. https://doi.org/10.1021/bc500208y.

95. Sanman LE, Bogyo M. Activity-based profiling of proteases. Annu Rev Biochem. 2014; 83:249-73. https://doi.org/10.1146/annurev-biochem-060713-035352.

96. Liu Y, Guo M. Chemical proteomic strategies for the discovery and development of anticancer drugs. Proteomics. 2014; 14:399-411. https://doi.org/10.1002/pmic.201300261.

97. Cravatt BF, Wright AT, Kozarich JW. Activity-based protein profiling: from enzyme chemistry to proteomic chemistry. Annu Rev Biochem. 2008; 77:383-414. https://doi.org/10.1146/annurev.biochem.75.101304.124125.

98. Chang JW, Nomura DK, Cravatt BF. A potent and selective inhibitor of KIAA1363/AADACL1 that impairs prostate cancer pathogenesis. Chem Biol. 2011; 18:476-84. https://doi.org/10.1016/j.chembiol.2011.02.008.

99. Kohnz RA, Mulvihill MM, Chang JW, Hsu KL, Sorrentino A, Cravatt BF, Bandyopadhyay S, Goga A, Nomura DK. Activity-based protein profiling of oncogene-driven changes in metabolism reveals broad dysregulation of PAFAH1B2 and 1B3 in cancer. ACS Chem Biol. 2015; 10:1624-30. https://doi.org/10.1021/acschembio.5b00053.

100. Goldberger NE, Hunter KW. A systems biology approach to defining metastatic biomarkers and signaling pathways. Wiley Interdiscip Rev Syst Biol Med. 2009; 1:89-96. https://doi.org/10.1002/wsbm.6.

101. Acosta-Martin AE, Lane L. Combining bioinformatics and MS-based proteomics: clinical implications. Expert Rev Proteomics. 2014; 11:269-84. https://doi.org/10.1586/14789450.2014.900446.

102. Carnielli CM, Winck FV, Paes Leme AF. Functional annotation and biological interpretation of proteomics data. Biochim Biophys Acta. 2015; 1854:46-54. https://doi.org/10.1016/j.bbapap.2014.10.019.

103. Ingenuity Pathway Analysis. Qiagen. https:// www.qiagenbioinformatics.com/products/ ingenuity-pathway-analysis/.

104. Kanehisa M, Sato Y, Kawashima M, Furumichi M, Tanabe M. KEGG as a reference resource for gene and protein annotation. Nucleic Acids Res. 2016; 44:D457-62. https://doi.org/10.1093/nar/gkv1070. 
105. Metacore.

Clarivate

Analytics.

http://ipscience.thomsonreuters.com/product/metacore.

106. Huang W, Sherman BT, Lempicki RA. Systematic and integrative analysis of large gene lists using DAVID bioinformatics resources. Nat Protoc. 2009; 4:44-57. https://doi.org/10.1038/nprot.2008.211.

107. Maere S, Heymans K, Kuiper M. BiNGO: a Cytoscape plugin to assess overrepresentation of gene ontology categories in biological networks. Bioinformatics. 2005; 21:3448-49. https://doi.org/10.1093/bioinformatics/bti551.

108. Carbon S, Ireland A, Mungall CJ, Shu S, Marshall B, Lewis S, and AmiGO Hub, and Web Presence Working Group. AmiGO: online access to ontology and annotation data. Bioinformatics. 2009; 25:288-89. https://doi.org/10.1093/bioinformatics/btn615.

109. Szklarczyk D, Franceschini A, Wyder S, Forslund K, Heller D, Huerta-Cepas J, Simonovic M, Roth A, Santos A, Tsafou KP, Kuhn M, Bork P, Jensen LJ, von Mering C. STRING v10: protein-protein interaction networks, integrated over the tree of life. Nucleic Acids Res. 2015; 43:D447-52. https://doi.org/10.1093/nar/gku1003.

110. Saito R, Smoot ME, Ono K, Ruscheinski J, Wang PL, Lotia S, Pico AR, Bader GD, Ideker T. A travel guide to Cytoscape plugins. Nat Methods. 2012; 9:1069-76. https://doi.org/10.1038/nmeth.2212.

111. Fernández JM, Hoffmann R, Valencia A. iHOP web services. Nucleic Acids Res. 2007; 35:W21-6. https://doi.org/10.1093/nar/gkm298.

112. Chen H, Sharp BM. Content-rich biological network constructed by mining PubMed abstracts. BMC Bioinformatics. 2004; 5:147. https://doi.org/10.1186/1471-2105-5-147.

113. Divoli A, Wooldridge MA, Hearst MA. Full text and figure display improves bioscience literature search. PLoS One. 2010; 5:e9619. https://doi.org/10.1371/journal.pone.0009619.

114. Perez-Riverol Y, Alpi E, Wang R, Hermjakob $H$, Vizcaíno JA. Making proteomics data accessible and reusable: current state of proteomics databases and repositories. Proteomics. 2015; 15:930-49. https://doi.org/10.1002/pmic.201400302.

115. Ling XB, Mellins ED, Sylvester KG, Cohen HJ. Urine peptidomics for clinical biomarker discovery. Adv Clin Chem. 2010; 51:181-213. https://doi.org/10.1016/S0065-2423(10)51007-2.

116. Frantzi M, Bhat A, Latosinska A. Clinical proteomic biomarkers: relevant issues on study design \& technical considerations in biomarker development. Clin Transl Med. 2014; 3:7. https://doi.org/10.1186/2001-1326-3-7.

117. Sahab ZJ, Semaan SM, Sang QX. Methodology and applications of disease biomarker identification in human serum. Biomark Insights. 2007; 2:21-43. https://doi.org/10.1177/117727190700200034.
118. Fu Q, Zhu J, Van Eyk JE. Comparison of multiplex immunoassay platforms. Clin Chem. 2010; 56:314-18. https://doi.org/10.1373/clinchem.2009.135087.

119. Shimizu Y, Furuya H, Bryant Greenwood P, Chan O, Dai Y, Thornquist MD, Goodison S, Rosser CJ. A multiplex immunoassay for the non-invasive detection of bladder cancer. J Transl Med. 2016; 14:31. https://doi.org/10.1186/s12967-016-0783-2.

120. Pan C, Korff A, Galasko D, Ginghina C, Peskind E, Li G, Quinn J, Montine TJ, Cain K, Shi M, Zhang J. Diagnostic values of cerebrospinal fluid T-Tau and $A \beta_{42}$ using meso scale discovery assays for alzheimer's disease. J Alzheimers Dis. 2015; 45:709-19. https://doi.org/10.3233/JAD-143099.

121. Meso Scale Diagnostics. https://www.mesoscale.com/.

122. Fredriksson S, Horecka J, Brustugun OT, Schlingemann J, Koong AC, Tibshirani R, Davis RW. Multiplexed proximity ligation assays to profile putative plasma biomarkers relevant to pancreatic and ovarian cancer. Clin Chem. 2008; 54:582-89. https://doi.org/10.1373/clinchem.2007.093195.

123. Blokzijl A, Friedman M, Pontén F, Landegren U. Profiling protein expression and interactions: proximity ligation as a tool for personalized medicine. J Intern Med. 2010; 268:232-45. https://doi.org/10.1111/j.1365-2796.2010.02256.x.

124. Tavoosidana G, Ronquist G, Darmanis S, Yan J, Carlsson L, Wu D, Conze T, Ek P, Semjonow A, Eltze E, Larsson A, Landegren UD, Kamali-Moghaddam M. Multiple recognition assay reveals prostasomes as promising plasma biomarkers for prostate cancer. Proc Natl Acad Sci USA. 2011; 108:8809-14. https://doi.org/10.1073/pnas.1019330108.

125. Truong M, Yang B, Jarrard DF. Toward the detection of prostate cancer in urine: a critical analysis. J Urol. 2013; 189:422-29. https://doi.org/10.1016/j.juro.2012.04.143.

126. Qoronfleh MW. Protein biomarker immunoassays opportunities and challenges. Drug Discov World. 2010; 12:19-28.

127. Giannico GA, Arnold SA, Gellert LL, Hameed O. New and emerging diagnostic and prognostic immunohistochemical biomarkers in prostate pathology. Adv Anat Pathol. 2017; 24:35-44. https://doi.org/10.1097/PAP.0000000000000136.

128. Goltz D, Holmes EE, Gevensleben H, Sailer V, Dietrich J, Jung M, Röhler M, Meller S, Ellinger J, Kristiansen G, Dietrich D. CXCL12 promoter methylation and PD-L1 expression as prognostic biomarkers in prostate cancer patients. Oncotarget. 2016; 7:53309-20. https://doi.org/10.18632/oncotarget.10786.

129. Filella X, Fernández-Galan E, Fernández Bonifacio R, Foj L. Emerging biomarkers in the diagnosis of prostate cancer. Pharm Genomics Pers Med. 2018; 11:83-94. https://doi.org/10.2147/PGPM.S136026.

130. Prager AJ, Peng CR, Lita E, McNally D, Kaushal A, Sproull M, Compton K, Dahut WL, Figg WD, Citrin D, Camphausen 
KA. Urinary aHGF, IGFBP3 and OPN as diagnostic and prognostic biomarkers for prostate cancer. Biomarkers Med. 2013; 7:831-41. https://doi.org/10.2217/bmm.13.112.

131. Theodorescu D, Schiffer E, Bauer HW, Douwes F, Eichhorn F, Polley R, Schmidt T, Schöfer W, Zürbig P, Good DM, Coon JJ, Mischak H. Discovery and validation of urinary biomarkers for prostate cancer. Proteomics Clin Appl. 2008; 2:556-70. https://doi.org/10.1002/prca.200780082.

132. Wu D, Ni J, Beretov J, Cozzi P, Willcox M, Wasinger V, Walsh B, Graham P, Li Y. Urinary biomarkers in prostate cancer detection and monitoring progression. Crit Rev Oncol Hematol. 2017; 118:15-26. https://doi.org/10.1016/j.critrevonc.2017.08.002.

133. Salido-Guadarrama AI, Morales-Montor JG, RangelEscareño C, Langley E, Peralta-Zaragoza O, Cruz Colin JL, Rodriguez-Dorantes M. Urinary microRNA-based signature improves accuracy of detection of clinically relevant prostate cancer within the prostate-specific antigen grey zone. Mol Med Rep. 2016; 13:4549-60. https://doi.org/10.3892/mmr.2016.5095.

134. Foj L, Ferrer F, Serra M, Arévalo A, Gavagnach M, Giménez $\mathrm{N}$, Filella X. Exosomal and non-exosomal urinary miRNAs in prostate cancer detection and prognosis. Prostate. 2017; 77:573-83. https://doi.org/10.1002/pros.23295.

135. Downes MR, Byrne JC, Pennington SR, Dunn MJ, Fitzpatrick JM, Watson RW. Urinary markers for prostate cancer. BJU Int. 2007; 99:263-68. https://doi.org/10.1111/j.1464-410X.2006.06610.x.

136. Kim JH, Hong SK. Potential utility of novel biomarkers in active surveillance of low-risk prostate cancer. BioMed Res Int. 2015; 2015:475920. https://doi.org/10.1155/2015/475920.

137. Fernandez C, Rifai N, Wenger AS, Mickey DD, Silverman LM. A preliminary study of urinary transferrin as a marker for prostatic cancer. Clin Chim Acta. 1986; 161:335-39. https://doi.org/10.1016/0009-8981(86)90018-5.

138. Lwaleed BA, Francis JL, Chisholm M. Urinary tissue factor levels in patients with bladder and prostate cancer. Eur J Surg Oncol. 2000; 26:44-49. https://doi.org/10.1053/ejso.1999.0739.

139. Stoeber K, Swinn R, Prevost AT, de Clive-Lowe P, Halsall I, Dilworth SM, Marr J, Turner WH, Bullock N, Doble A, Hales CN, Williams GH. Diagnosis of genito-urinary tract cancer by detection of minichromosome maintenance 5 protein in urine sediments. J Natl Cancer Inst. 2002; 94:1071-79. https://doi.org/10.1093/jnci/94.14.1071.

140. Rogers CG, Yan G, Zha S, Gonzalgo ML, Isaacs WB, Luo J, De Marzo AM, Nelson WG, Pavlovich CP. Prostate cancer detection on urinalysis for alpha methylacyl coenzyme a racemase protein. J Urol. 2004; 172:1501-03. https://doi.org/10.1097/01.ju.0000137659.53129.14.
141. Hutchinson LM, Chang EL, Becker CM, Shih MC, Brice M, DeWolf WC, Gaston SM, Zetter BR. Use of thymosin beta15 as a urinary biomarker in human prostate cancer. Prostate. 2005; 64:116-27. https://doi.org/10.1002/pros.20202.

142. M'Koma AE, Blum DL, Norris JL, Koyama T, Billheimer D, Motley S, Ghiassi M, Ferdowsi N, Bhowmick I, Chang SS, Fowke JH, Caprioli RM, Bhowmick NA. Detection of pre-neoplastic and neoplastic prostate disease by MALDI profiling of urine. Biochem Biophys Res Commun. 2007; 353:829-34. https://doi.org/10.1016/j.bbrc.2006.12.111.

143. Schostak M, Schwall GP, Poznanović S, Groebe K, Müller M, Messinger D, Miller K, Krause H, Pelzer A, Horninger W, Klocker H, Hennenlotter J, Feyerabend S, et al. Annexin A3 in urine: a highly specific noninvasive marker for prostate cancer early detection. J Urol. 2009; 181:343-53. https://doi.org/10.1016/j.juro.2008.08.119.

144. Fujita K, Ewing CM, Chan DY, Mangold LA, Partin AW, Isaacs WB, Pavlovich CP. Endoglin (CD105) as a urinary and serum marker of prostate cancer. Int J Cancer. 2009; 124:664-69. https://doi.org/10.1002/ijc.24007.

145. True LD, Zhang H, Ye M, Huang CY, Nelson PS, von Haller PD, Tjoelker LW, Kim JS, Qian WJ, Smith RD, Ellis WJ, Liebeskind ES, Liu AY. CD90/THY1 is overexpressed in prostate cancer-associated fibroblasts and could serve as a cancer biomarker. Mod Pathol. 2010; 23:1346-56. https://doi.org/10.1038/modpathol.2010.122.

146. Cheng HL, Huang HJ, Ou BY, Chow NH, Chen YW, Tzai TS, Wu CJ, Chen SH. Urinary CD14 as a potential biomarker for benign prostatic hyperplasia - discovery by combining MALDI-TOF-based biostatistics and ESI-MS/ MS-based stable-isotope labeling. Proteomics Clin Appl. 2011; 5:121-32. https://doi.org/10.1002/prca.201000011.

147. Morgan R, Boxall A, Bhatt A, Bailey M, Hindley R, Langley S, Whitaker HC, Neal DE, Ismail M, Whitaker H, Annels N, Michael A, Pandha H. Engrailed-2 (EN2): a tumor specific urinary biomarker for the early diagnosis of prostate cancer. Clin Cancer Res. 2011; 17:1090-98. https://doi.org/10.1158/1078-0432.CCR-10-2410.

148. Katafigiotis I, Tyritzis SI, Stravodimos KG, Alamanis C, Pavlakis K, Vlahou A, Makridakis M, Katafigioti A, Garbis SD, Constantinides CA. Zinc $\alpha 2$-glycoprotein as a potential novel urine biomarker for the early diagnosis of prostate cancer. BJU Int. 2012; 110:E688-93. https://doi.org/10.1111/j.1464-410X.2012.11501.x.

149. Haj-Ahmad TA, Abdalla MA, Haj-Ahmad Y. Potential urinary protein biomarker candidates for the accurate detection of prostate cancer among benign prostatic hyperplasia patients. J Cancer. 2014; 5:103-14. https://doi.org/10.7150/jca.6890.

150. Davalieva K, Kiprijanovska S, Komina S, Petrusevska G, Zografska NC, Polenakovic M. Proteomics analysis of urine reveals acute phase response proteins as candidate 
diagnostic biomarkers for prostate cancer. Proteome Sci. 2015; 13:2. https://doi.org/10.1186/s12953-014-0059-9.

151. Vermassen T, Van Praet C, Lumen N, Decaestecker K, Vanderschaeghe D, Callewaert N, Villeirs G, Hoebeke P, Van Belle S, Rottey S, Delanghe J. Urinary prostate protein glycosylation profiling as a diagnostic biomarker for prostate cancer. Prostate. 2015; 75:314-22. https://doi.org/10.1002/pros.22918.
152. Hsiao CJ, Tzai TS, Chen CH, Yang WH, Chen CH. Analysis of urinary prostate-specific antigen glycoforms in samples of prostate cancer and benign prostate hyperplasia. Dis Markers. 2016; 2016:8915809. https://doi.org/10.1155/2016/8915809. 